\title{
PEMILIHAN BIBIT KELAPA MENGGUNAKAN METODE NEAREST MEAN CLASSIFIER UNTUK MASYARAKAT PETANI KELAPA DI KABUPATEN INDRAGIRI HILIR
}

\author{
${ }^{1}$ Muh. Rasyid Ridha, ${ }^{2}$ Fitri Yunita \\ ${ }^{1,2}$ Program Studi Sistem Informasi, Fakultas Teknik dan Ilmu Komputer \\ Universitas Islam Indragiri (UNISI) \\ Jl. Provinsi No.01 Tembilahan Hulu, Indragiri Hilir, Riau - Indonesia \\ Email: rasyid4sky@gmail.com, fitriyun@gmail.com
}

\begin{abstract}
ABSTRAK
Coconut is an annual plant that can only produce after about five years, therefore a careful plan must be made regarding the selection of planting material or coconut seeds to avoid both material and time loss. Mistakes in selecting seeds can make coconut plants unable to produce optimally, even though they have been treated with appropriate technical operational standards for cultivation. The specific target in this study is to compile a classification system for coconut seeds using the Nearest Mean Classifier (NMC) Method, the classification of coconut seeds into grade $A$, grade $B$ and grade $C$. The results of the classification system $10 \times 10$ - fold crossvalidation in each category. The quality of coconut seedlings, namely: Grade A (80-85\%) resulted in an average accuracy of $56.791 \%$ with a standard deviation of $12.05715 \%$. Grade B $(70-75 \%)$ has an average accuracy of $52.525 \%$ with a standard deviation of $7.481074 \%$. Grade C (60-65\%) has an average accuracy of $62.002 \%$ with a standard deviation of $16.36763 \%$. It can be stated that Grade $C$ has the highest percentage with a distance of $0.379 \%$ and a similarity percentage of $62 \%$. The final result of evaluation from experimental data globally, has an average accuracy of $86.67 \%$. To get a high similarity percentage, a lot of training data must be carried out on the coconut seed quality classification system.
\end{abstract}

Keywords - Coconut Seed, Nearest Mean Classifier, Indragiri Hilir

\section{Pendahuluan}

Kelapa memiliki variasi genetis yang besar, secara umum pembiakannya dilakuka sacara generative. Penyediaan bibit atau bahan tanaman yang berkualitas baik akan lebih menjamin berhasilnya pertanaman kelapa itu sendiri. Maka memilih bibit kepala yang berkualitas merupakan suatu keharusan agar diperoleh tanaman kelapa yang mampu berproduksi dengan baik. Tanaman kelapa merupakan salah satu komoditi perkebunan yang paling penting di Kabupaten Indragiri Hilir, menurut data (Dinas Perkebunan, 2015) lahan perkebunan kelapa di Kabupaten Indragiri Hilir mencapai $430.069 \mathrm{Ha}$, dan tanaman tua dan rusak mencapai 100.285 Ha yang tersebar dibeberapa kecamatan seperti, Kec. Keritang, Kempas, Enok, Tembilahan Hulu, dan Kec. Pulau Burung. Untuk memanfaatkan lahan perkebunan kelapa yang sudah rusak perlu dilakukan penanaman kelapa yang baru. Namun permasalahan yang terjadi adalah banyaknya kesulitan atau kendala untuk mengklasifikasi dan mengenali bibit kelapa yang cocok untuk digunakan, seperti kesulitan dalam memprediksi kualitas bibit kelapa ke dalam kelas rerata grade C (60-65\%), kelas rerata grade $B$ (70$75 \%)$, dan kelas rerata grade A (80-85\%) berdasarkan bentuk, ukuran dan warna RGB.

Perkembangan piranti keras dan piranti lunak komputer menjadi perhatian penting dalam perkembangannya yang begitu pesat dan didukung dengan konsep klasifikasi dan pengenalan pola, serta mempertimbangkan teknik-teknik pengolahaan citra, diharapkan sistem klasifikasi bibit kelapa dapat diterapkan sebagai alat bantu yang dapat mempercepat pekerjaan manusia. Ada beberapa metode yang dapat digunakan untuk melakukan klasifikasi salah satunya adalah Nearest Mean Classifier (NMC).

Nearest Mean Classifier (NMC) itu sendiri merupakan metode pemilah linier sederhana untuk mengklasifikasi sebuah objek yang kedalam kelas terdekatnya tidak diketahui. NMC mudah dimengerti dan diimpelmentasikan karena tidak membuat asumsi tentang data ruang figur. Setiap 
kelas diwakili oleh rerata vektor fitur objek sekelas berdasarkan data pembentuk kelas. Merujuk pada uraian latar belakan di atas, maka yang dijadikan topik pada penelitian ini yaitu klasifikasi kualitas bibit kelapa menggunakan metode Nearest Mean Classifier, diharapkan menjadi salah satu kontribusi dalam membudayakan, memajukan dan mengembangkan sentra produktifitas kelapa di Kabupaten Indragiri Hilir.

Berdasarkan dari uraian latarbelakang di atas, maka rumusan masalah dari penelitian ini yaitu: bagaimana menerapkan metode Nearest Mean Classifier dalam melakukan klasifikasi kualitas bibit kelapa?. Tujuan penelitian ini adalah menerapkan metode Nearest Mean Classifier dalam melakukan klasifikasi kualitas bibit kelapa.

Kontribusi ataupun manfaat dari penelitian ini yaitu: Memberikan gambaran teknik citra digital dan Nearest Mean Classifier dalam mengklasifikasikan kualitas bibit kelapa. Membantu mengasilkan klasifikasi kualitas kelapa yang lebih cepat dan tepat untuk dijadikan rujukan dalam pengambilan keputusan. Memberikan informasi kualitas bibit kelapa ke dalam kelas rerata grade C (60-65\%), kelas rerata grade B (70-75\%), dan kelas rerata dan, grade A ( $80-85 \%$ ) berdasarkan bentuk dan warna RGB.

\section{TINJAUAN PUSTAKA}

\subsection{Nearest Mean Classifier (NMC)}

Nearest Mean Classifier (NMC) di kembangkan dalam penelitian untuk prediksi objek seperti buah-buahan yang bertindak sebagai pemilah menggunakan kemiripan antar pola untuk melakukan klasifikasi. Untuk setiap kelas, NMC menghitung rerata kelas (centroid) dari data sampel. Perolehan kemiripan melalui perhitungan jarak Euclidean antara pola yang tidak diketahui dengan centroid dari data sampel. NMC mengklasifikasikan sembarang pola yang tidak diketahui ke kelas dengan centroid terdekat dengan pola yang akan dikenali. NMC berhasil diterapkan pada banyak masalah klasifikasi dan menunjukkan hasil yang baik. Selain itu NMC memberikan kemampuan yang bagus untuk persoalan sampel kecil dimana jumlah sampel jauh lebih kecil dari jumlah fitur.

Nearest Mean Classifier merupakan pemilah linier sederhana untuk mengklasifikasikan sebuah objek yang tidak diketahui ke dalam suatu kelas terdekat. Dapat juga disebut sebagai metode Minimum Euclidean Distance Classifier. Metode ini mudah dimengerti dan mudah diimplementasikan karena tidak membuat asumsi tentang distribusi data dalam ruang fitur. Setiap cluster diwakili oleh rerata vektor fitur objek yang sekelas berdasarkan data training. Rerata vektor fitur class mean menjadi titik pusat kelas atau istilah lainnya adalah cluster centroid. Selanjutnya klasifikasi didasarkan atas jarak terdekat vektor fitur objek dengan vektor fitur class mean. [1]. Ilustrasi pada Gambar 1 di bawah ini menunjukkan dua buah kelas (cluster) yang diwakili oleh mean kelas (class mean/cluster centroid)

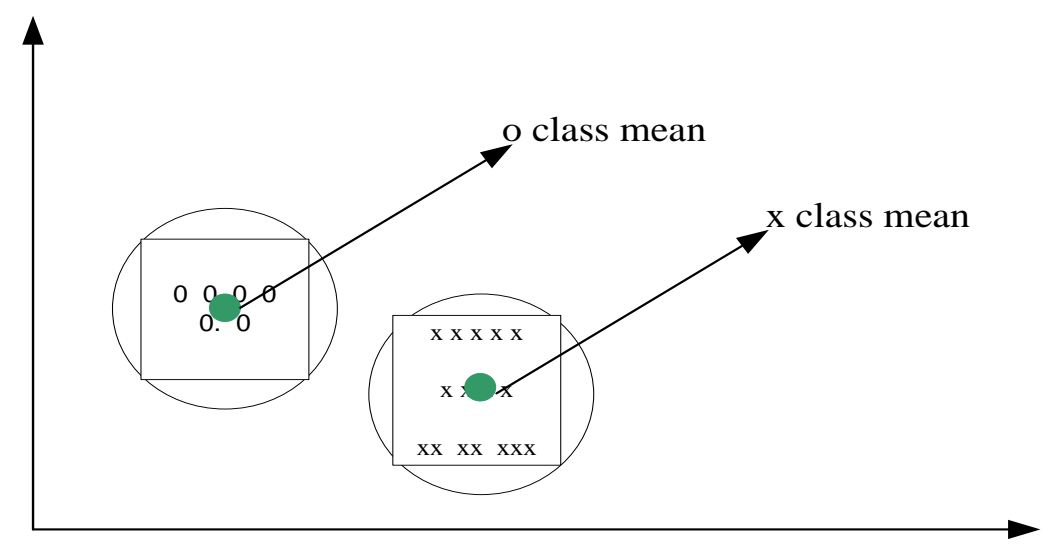

Gambar 1. Dua Buah Class Mean 
Class mean pada masing-masing kelas dihitung berdasarkan nilai rerata fitur objek yang berada pada kelas yang sama. Aturan klasifikasi pada metode ini dijelaskan sebagaimana berikut; Jika diberikan dua buah kelas $w_{1}$ dan $w_{2}$. Vektor dituliskan sebagai $\left\{\mathrm{x}_{1}, \ldots, \mathrm{x}_{n}\right\}$, jika $\bar{x}_{\text {(i) }}$ adalah mean kelas $\mathrm{W}_{\mathrm{i}}$ maka untuk objek baru $\mathrm{z}$ direpresentasikan dalam ruang sebagai $\mathrm{z}_{\mathrm{x}}$, maka aturan klasifikasi didefenisikan sebagai berikut:

- Klasifikasikan z kedalam kelas $\mathrm{w}_{1}$ jika dan hanya jika $\mathrm{D}^{2}\left(z, \bar{x}_{(1)}\right)<\mathrm{D}^{2}\left(z, \bar{x}_{(2)}\right)$

- Klasifikasikan z kedalam kelas $\mathrm{w}_{2}$ jika dan hanya jika $\mathrm{D}^{2}\left(\mathrm{z}, \bar{x}_{(2)}\right)<\mathrm{D}^{2}\left(\mathrm{z}, \bar{x}_{(1)}\right)$

Algoritma pemilah kelas terdekat adalah sebagai berikut

1. Tentukan mean vektor fitur $(\mathrm{m})$ untuk setiap kelas.

2. Untuk setiap objek, hitung jaraknya (norma vektor) ke setiap mean (m)

3. Objek di klasifikasikan ke kelas yang jaraknya minimum.

Algoritma tersebut di atas dapat di ilustrasikan oleh Gambar 2 di bawah ini :

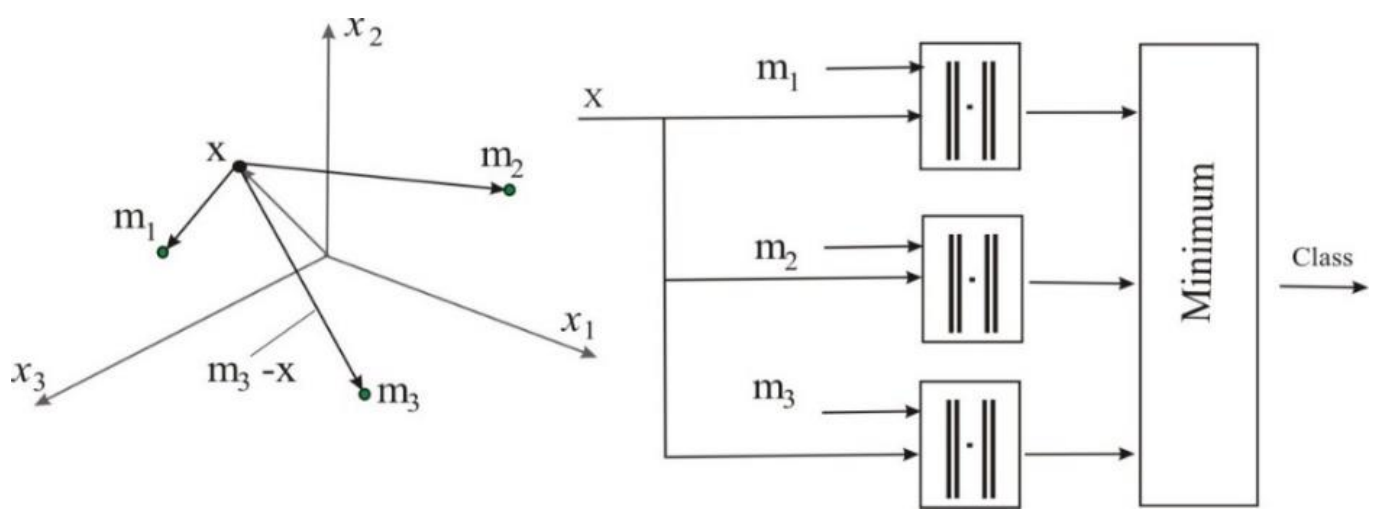

\section{Gambar 2. Ilustrasi Pemilah Jarak Minimum}

Keterangan: $m_{1}, m_{2}, m_{3}$ masing adalah mean kelas pertama, kedua dan ketiga. $x$ adalah objek uji. ||.|| adalah norma vektor yang menunjukkan jarak antara objek dengan mean masing-masing kelas. Jarak euclidean minimum akan menentukan kelas objek tersebut.

\subsection{Sistem}

Merupakan jaringan kerja dari prosedur-prosedurnya yang saling berhubungan, berkumpul bersama untuk melakukan suatu tindakan atau untuk menyelesaikan sasaran tertentu. Prosedur adalah urutan yang tepat dari tahapan-tahapan instruksi yang menerangkan apa (what) yang harus dikerjakan, siapa (who) yang mengerjakannya, kapan (when) dikerjakan dan bagaimana (how) mengerjakannya, [2]

\subsection{Klasifikasi}

Menentukan sebuah record data baru ke salah satu dari beberapa katagori/kelas yang telah didefinisikan sebelumnya. Disebut juga dengan supervised learning. Berikut beberapa aplikasi dari klasifikasi; a) Penjualan langsung (direct marketing) tujuannya mengurangi cost surat menyurat dengan menentukan (targeting) satu set konsumen yang mempunyai kesamaan dalam membeli produk telepon selular baru; b) Fraud detection tujuannya memprediksi kasus transaksi curang dengan menggunakan kartu kredit; c) Customer Attrition/churn tujuannya memprediksi pelanggan mana yang akan perpindah ke kompetitor kita, [3] 


\subsection{Citra Digital}

Citra digital adalah citra dengan $f(x, y)$ yang nilainya didigitalisasikan baik dalam koordinat spasialnya maupun dalam gray level-nya. Sebuah citra diubah ke dalam bentuk digital agar mudah diolah atau disimpan dalam memori komputer atau media lain, [4] Citra ialah istilah lain untuk gambar sebagai salah satu komponen multimedia yang memiliki peranan penting dalam bentuk informasi visual, [5]

\subsection{Pengenalan Pola}

Pattern recognition merupakan teknik yang bertujuan untuk mengklasifikasikan citra yang telah diolah sebelumnya berdasarkan kesamaan atau kemiripan ciri yang dimilikinya. Secara umum teknik pengenalan pola bertujuan mengklasifikasikan dan mendiskripsi pola atau objek yang komplek melalui pengukuran sifat atau ciri-ciri objek bersangkutan. Prinsip kerjanya menirukan kemampuan manusia mengenali objek-objek berdasarkan ciri-ciri dan pengetahuan yang pernah diamatinya dari objek tersebut. Cara kerjanya, mengklasifikasikan objek ke dalam kelas tertentu berdasarkan parameter yang telah disimpan atau ditentukan sebelumnya. Contoh aplikasi speech recognition, data mining, biometrics, dll.

Manusia memiliki kemampuan yang luar biasa didalam pengenalan objek berdasarkan ciri-ciri atau pengetahuan yang pernah diamatinya. Misalnya manusia dengan mudah membedakan antara burung dengan kupu-kupu, kursi dengan meja. Mempelajari cara bagaimana manusia mempelajari pola merupakan masalah yang sangat menarik, [6]

Proses pengenalan pola mendeskripsikan tahap-tahapan dalam pengenalan pola. Hal ini di maksudkan agar adanya langkah-langkah terstruktur dalam melakukan pengenalan pola yaitu: a) Data (gambar, bunyi, teks) untuk dikelaskan; b) Menghilankan gangguan/menormalkan gambar (Image processing); c) Pengiraan citra; dan d) Pengenalan kelas (mengambil keputusan).

\subsection{Kelapa}

Kelapa (Cocos nucifera) merupakan pohon yang mempunyai nilai ekonomi yang tinggi. Buah kelapa terbungkus serabut dan batok yang cukup kuat. Setiap bagian dari pohon kelapa dapat dimanfaatkan bagi kepentingan manusia. Oleh karena itu, tanaman kelapa sering disebut sebagai pohon kehidupan, [7]

\subsection{Metode Penelitian}

Agar pembuatan sistem klasifikasi kualitas bibit kelapa dapat berjalan dengan baik dan terstruktur, maka tahapan dalam penelitian ini digambarkan pada sketsa pemrosesan data model waterfall sebagaimana berikut:

1 Tahapan Pengumpulan data. Pada tahap Pengumpulan data dalam penelitian dimaksudkan guna mendapatkan bahan, keterangan, kenyataan, dan informasi yang bisa dipercaya. Analisa dan ekstraksi fitur bibit kelapa dalam tahapan perencanaan meliputi fitur pengumpulan data dan observasi yang dilakukan di Kabupaten Indragiri Hilir yang tersebar di 5 (lima) kecamatan dan Dinas Perkebunan Kabupaten Indragiri Hilir, memiliah data bibit kelapa yang akan di klasifikasi, klasifikasi didasarkan pada bentuk, ukuran dan warna RGB. Memilah citra input dan uji, melakukan klasifikasi citra latih dan uji, mengklasifikasikan citra fitur bibit kelapa.

2 Tahapan Desain Program. Setelah data-data yang diperlukan terkumpul langkah selanjutya adalah perancangan program sistem klasifikasi kualitas bibit kelapa. Penelitian ini menggunakan konsep data mining dengan menggunakaan metode Neares Mean Classifier (NMC). Merancang bentuk arsitektur sistem klasifikasi kualitas bibit kelapa yang menggambarkan cara kerja aplikasi sistem klasifikasi kualitas bibit kelapa. 


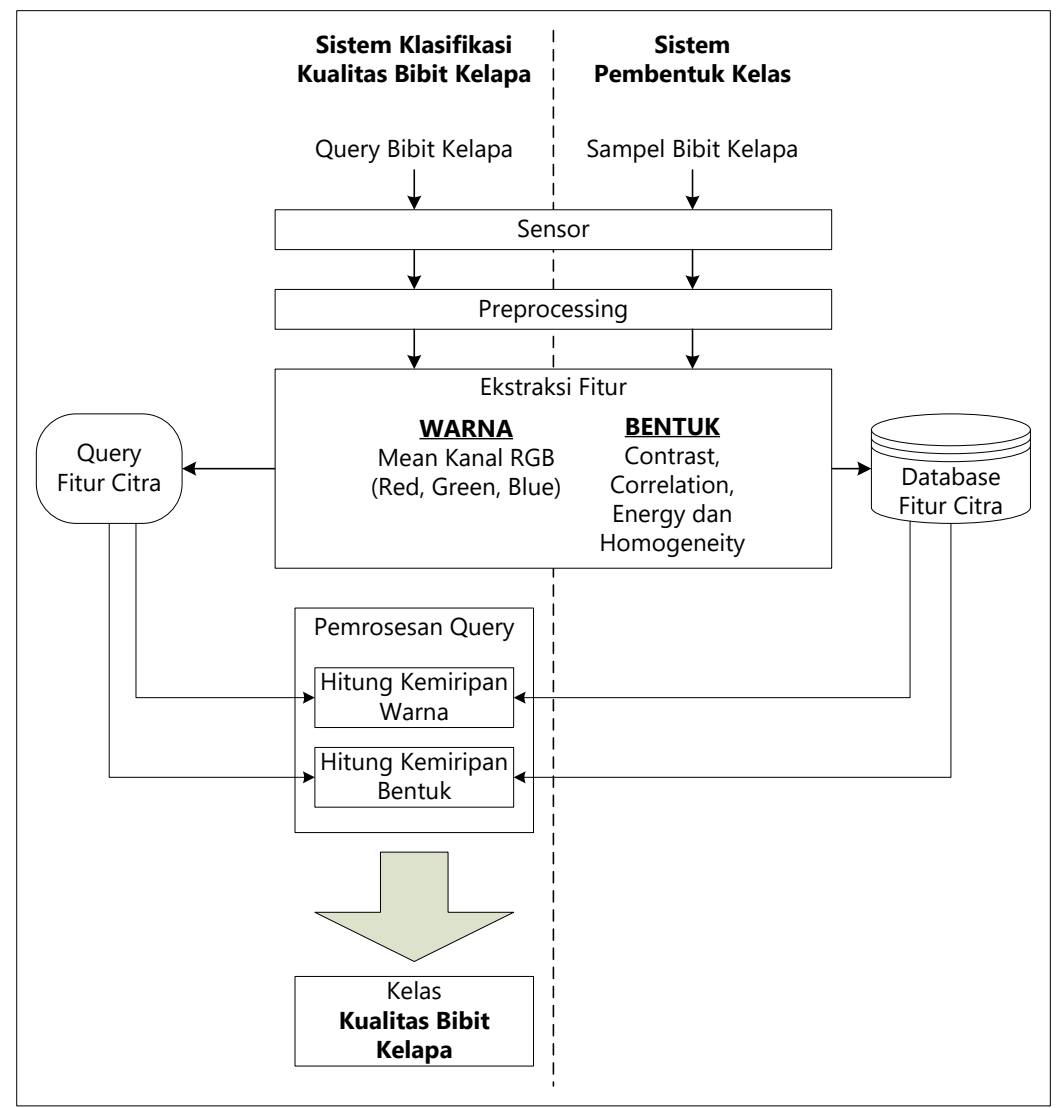

Gambar 3. Arsitektur Sistem Klasifikasi Kualitas Bibit Kelapa

3 Tahapan Pembuatan Program. Tahapan pembuatan program dilakukan dengan mengacu pada hasil perancangan yang di uraikan pada tahapan perancangan yang sesuai dengan kebutuhan.

4 Tahapan Pengujian. Tahapan pengujian sistem ini dilakukan untuk menguji apakah sistem sudah siap digunakan, pengujian sistem dilakukan dengan prosedur White-Box dan Black-Box.

5 Tahapan Analisa. Tahap ini merupakan tahapan menganalisa, yaitu apakah sistem yang digunakan membantu pengguna sistem atau sesuai dengan kebutuhan.

\section{HASIL DAN PEMBAHASAN}

\subsection{Analisa Sistem}

Penelitian ini yang menjadi inputan sistem klasifikasi kualitas citra bibit kelapa adalah berupa citra bibit kelapa. Citra sampel berjumlah 30 buah (3 kelas kualitas bibit kelapa, masing-masing kelas 10 citra).

Tabel I. Data Citra Latih

\begin{tabular}{ccc}
\hline No. & Kelas & Jumlah \\
\hline 1 & Kelas rata-rata Grade A & 10 \\
2 & Kelas rata-rata Grade B & 10 \\
3 & Kelas rata-rata Grade C & 10 \\
\hline \hline & Total & 30 \\
\hline
\end{tabular}

Citra digital adalah citra dengan $f(x, y)$ yang nilainya didigitalisasikan baik dalam koordinat spasialnya maupun dalam gray level-nya., [4] Citra ialah istilah lain untuk gambar sebagai salah satu komponen multimedia yang memiliki peranan penting dalam bentuk informasi visual, [5]

Citra uji berjumlah 30 buah ( 3 kelas kualitas kopra, masing-masing kelas 10 citra). Semua citra, baik citra sample ataupun citra uji terlebih dahulu akan dikonversi ke format BMP dan diubah resolusinya menjadi $640 \times 480$ piksel. 
1. Analisa Proses

Tiap kelas kualitas dibedakan berdasarkan nilai fitur warna (red, green, blue) dan tekstur (contrast, correlation, energy dan homogeneity). Semakin berwarna coklat keabuan-abuan,dan bentuk lonjong dan pipih bagian bawah maka bibit kelapa tersebut semakin baik kualitasnya.

Setelah diketahui karakteristik kelas kualitas bibit kelapa, maka analisa proses pembentukan kelas bisa dilakukan. Proses pembentukan kelas diawali dengan melakukan ektraksi fitur citra data latih. Tiap citra akan diekstrak untuk mendapatkan nilai red, green, blue dari variabel warna kemudian contrast, correlation, energy dan homogeneity dari variabel tekstur. Hasilnya akan disimpan di dalam database fitur citra, yakni di dalam tabel fitur citra latih.

Proses Perhitungan Jarak dan Identifikasi Kualitas Bibit Kelapa, proses ini diawali dengan pemanggilan citra uji (Citra Query) yang ingin dicari kelas kualitasnya, hasil citra query akan diekstrak untuk mendapatkan vector fitur citra query,

Setelah didapatkan vektor fitur Red, Green dan Blue dari variabel warna kemudian energy, contrast, correlation dan homogeneity dari variabel tekstur. Perbandingan tersebut dapat dilakukan dengan cara menghitung jarak euclidean distance yang merupakan selisih nilai piksel antara 2 vektor tersebut. Adapun rumus euclidean distance ditunjukkan pada persamaan berikut ini:

$$
\text { Dist }(\mathrm{i}, \mathrm{k})=\sqrt{\sum_{i=j}^{D}\left(i_{j}-k_{j}\right)^{2}} \text {, }
$$

Dengan dist $(\mathrm{i}, \mathrm{k})$ adalah jarak euclidean antara vektor $\mathrm{i}$ dan vektor $\mathrm{k}$

$\mathrm{i}_{\mathrm{j}} \quad=$ komponen $\mathrm{ke} \mathrm{j}$ dari vektor $\mathrm{i}$

$\mathrm{k}_{\mathrm{j}} \quad=$ komponen $\mathrm{ke} \mathrm{j}$ dari vektor $\mathrm{k}$

$\mathrm{D} \quad=$ adalah jumlah komponen pada vektor $\mathrm{i}$ dan vektor $\mathrm{k}$.

Dari hasil perhitunga jarak euclidean tersebut dapat ditentukan suatu citra query adalah mirip bila memiliki jarak yang paling dekat atau nilainya paling kecil.

2. Analisis Citra Latih

Pada Tabel 4 merupakan hasil dari proses fitur latih, kualitas bibit kelapa dibagi kedalam kelas bibit Grade A (80-85)\%, Grade A (70-7)\%, dan Grade C (60-65)\% berdasarkan variabel warna RGB (Red Green Blue).dimana dilakukan citra latih untuk 30 Jenis Bibit Kelapa yang berbeda yang dikelompokkan berdasarkan Grade A, Grade B dan Grade C.

Tabel 2. Database Vector Fitur Citra Latih

\begin{tabular}{cccclllll}
\hline \multirow{2}{*}{ No } & \multicolumn{3}{c}{ Warna RGB } & \multicolumn{3}{c}{ Texsture } \\
& Red & green & Blue & contrast & correlation & energy & homogeneity & Kelas \\
(Grade) \\
\hline 1 & 207 & 159 & 127 & 0.19549 & 0.92197 & 0.52511 & 0.94904 & $\mathrm{~A}$ \\
2 & 191 & 165 & 141 & 0.38007 & 0.85114 & 0.53196 & 0.91931 & $\mathrm{~A}$ \\
3 & 198 & 182 & 156 & 0.28098 & 0.85695 & 0.59057 & 0.94675 & $\mathrm{~A}$ \\
4 & 194 & 177 & 150 & 0.38497 & 0.82575 & 0.59906 & 0.92838 & $\mathrm{~A}$ \\
5 & 190 & 170 & 149 & 0.344 & 0.88702 & 0.51422 & 0.92907 & $\mathrm{~A}$ \\
6 & 216 & 189 & 156 & 0.16532 & 0.89522 & 0.49762 & 0.95973 & $\mathrm{~A}$ \\
7 & 197 & 162 & 132 & 0.15753 & 0.94251 & 0.60499 & 0.9676 & $\mathrm{~A}$ \\
8 & 179 & 152 & 126 & 0.19365 & 0.93941 & 0.55527 & 0.96952 & $\mathrm{~A}$ \\
9 & 167 & 143 & 121 & 0.50924 & 0.87592 & 0.51844 & 0.93899 & $\mathrm{~A}$ \\
10 & 170 & 148 & 123 & 0.39577 & 0.90232 & 0.47072 & 0.94541 & $\mathrm{~A}$ \\
11 & 169 & 151 & 132 & 0.53944 & 0.85987 & 0.49505 & 0.92654 & $\mathrm{~B}$ \\
12 & 176 & 136 & 108 & 0.37075 & 0.92512 & 0.40051 & 0.9498 & $\mathrm{~B}$ \\
13 & 182 & 148 & 119 & 0.19421 & 0.95022 & 0.43443 & 0.95427 & $\mathrm{~B}$ \\
14 & 166 & 133 & 117 & 0.3873 & 0.9244 & 0.43754 & 0.93494 & $\mathrm{~B}$ \\
15 & 188 & 145 & 119 & 0.28961 & 0.92834 & 0.42736 & 0.94186 & $\mathrm{~B}$ \\
16 & 185 & 166 & 146 & 0.24684 & 0.92728 & 0.48688 & 0.94574 & $\mathrm{~B}$ \\
17 & 190 & 159 & 136 & 0.24722 & 0.93015 & 0.4345 & 0.94791 & $\mathrm{~B}$ \\
18 & 193 & 160 & 134 & 0.21519 & 0.935 & 0.46796 & 0.96324 & $\mathrm{~B}$ \\
19 & 213 & 185 & 151 & 0.34537 & 0.842 & 0.49011 & 0.94002 & $\mathrm{~B}$ \\
20 & 182 & 155 & 132 & 0.22212 & 0.93376 & 0.51685 & 0.96795 & $\mathrm{~B}$ \\
21 & 189 & 160 & 136 & 0.18885 & 0.92558 & 0.56785 & 0.96571 & $\mathrm{C}$ \\
22 & 191 & 165 & 141 & 0.14484 & 0.94504 & 0.52099 & 0.96843 & $\mathrm{C}$ \\
\hline
\end{tabular}

Ridha, Pemilihan Bibit Kelapa Menggunakan Metode Nearest Mean Classifier Untuk Masyarakat Petani Kelapa Di Kabupaten Indragiri Hilir 


\begin{tabular}{lllllllll}
\hline 23 & 170 & 141 & 122 & 0.93561 & 0.80219 & 0.45287 & 0.92195 & $\mathrm{C}$ \\
24 & 182 & 155 & 136 & 0.45029 & 0.89404 & 0.40869 & 0.95395 & $\mathrm{C}$ \\
25 & 189 & 161 & 138 & 0.29611 & 0.92038 & 0.46095 & 0.95042 & $\mathrm{C}$ \\
26 & 195 & 169 & 148 & 0.52735 & 0.85075 & 0.47835 & 0.92733 & $\mathrm{C}$ \\
27 & 212 & 187 & 169 & 0.28504 & 0.86161 & 0.42752 & 0.91608 & $\mathrm{C}$ \\
28 & 195 & 173 & 149 & 0.21311 & 0.92172 & 0.50081 & 0.94931 & $\mathrm{C}$ \\
29 & 183 & 145 & 120 & 0.39593 & 0.90532 & 0.37351 & 0.91268 & $\mathrm{C}$ \\
\hline \hline 30 & 180 & 148 & 131 & 0.53324 & 0.86049 & 0.46606 & 0.9237 & $\mathrm{C}$ \\
\hline
\end{tabular}

3. Analisis Citra Uji

Misalkan kita ambil satu contoh bibit kelapa ada sebuah citra query yang belum di ketahui masuk label kelasnya dan masuk kualitas Grade A,Grade B atau Grade C. Vektor Tersebut yaitu: red $=181$, green $=149$ dan blue $=132$. Adapun tahapan perhitungan menggunakan Nearest mean classifier (NMC) adalah sebagai berikut: Menghitung jarak antara vektor fitur citra query dengan database vektor fitur data citra latih pada Tabel 3 menggunakan rumus euclidean distance.

$$
\begin{aligned}
& \mathrm{A} \quad=(\mathrm{x} 1, \mathrm{y} 1) \quad \mathrm{B}=\mathrm{x} 2, \mathrm{y} 2) \\
& \mathrm{D}(\mathrm{A}, \mathrm{B}) \quad=\sqrt{(x 2-x 1)^{2}+(y 2-y 1)^{2}} \\
& \text { Dalam } \mathrm{R}^{\mathrm{n}} \\
& \mathrm{A}=(\mathrm{x} 1, \mathrm{x} 2, \mathrm{x} 3, \ldots \mathrm{xn}) \quad \mathrm{B}=(\mathrm{y} 1, \mathrm{y} 2, \mathrm{y} 3, \ldots \mathrm{yn})
\end{aligned}
$$

Disederhanakan menjadi:

$\mathrm{D}(\mathrm{A}, \mathrm{B}) \quad=\sqrt{(y n-x n)^{2}+(y n-1-x n-1)^{2}+\cdots(y 1-x 1)}$

Masing Grade A, Grade B dan Grade C, Nilai RGB diambil dari data citra latih kemudian dicari nilai Mean untuk masing RGB, untuk menghitung jarak ke citra query menggunakan rumus

\begin{tabular}{|c|c|c|c|c|c|c|c|}
\hline $\begin{array}{l}\text { Kelas } \\
\text { (Grade) }\end{array}$ & $\begin{array}{l}11= \\
\text { Red }\end{array}$ & $\begin{array}{c}\mathrm{i} 2= \\
\text { Green }\end{array}$ & $\begin{array}{l}\text { i3 }= \\
\text { Blue }\end{array}$ & & Mear & & Jarak ke citra query [ $\left.\begin{array}{llll}181 & 149 & 132\end{array}\right]$ \\
\hline \multirow{10}{*}{ Grade A } & 207 & 159 & 127 & \multirow{10}{*}{190} & \multirow{10}{*}{164} & \multirow{10}{*}{138} & \\
\hline & 191 & 165 & 141 & & & & \\
\hline & 198 & 182 & 156 & & & & $\sqrt{(190-181)^{2}+(164-149)^{2}+(138-132)^{2}}$ \\
\hline & 194 & 177 & 150 & & & & $\sqrt{(9)^{2}+(15)^{2}+(6)^{2}}$ \\
\hline & 190 & 170 & 149 & & & & \\
\hline & 216 & 189 & 156 & & & & $\sqrt{81+225+36}$ \\
\hline & 197 & 162 & 132 & & & & \\
\hline & 179 & 152 & 126 & & & & $=\sqrt{342}=18,49$ \\
\hline & 167 & 143 & 121 & & & & \\
\hline & 170 & 148 & 123 & & & & \\
\hline \multirow{10}{*}{ Grade B } & 169 & 151 & 132 & \multirow{10}{*}{184} & \multirow{10}{*}{153} & \multirow{10}{*}{129} & \\
\hline & 176 & 136 & 108 & & & & \\
\hline & 182 & 148 & 119 & & & & $\sqrt{(184-181)^{2}+(153-149)^{2}+(129-132)^{2}}$ \\
\hline & 166 & 133 & 117 & & & & $\sqrt{(3)^{2}+(4)^{2}+(-3)^{2}}$ \\
\hline & 188 & 145 & 119 & & & & \\
\hline & 185 & 166 & 146 & & & & $\sqrt{9+16+9}$ \\
\hline & 190 & 159 & 136 & & & & \\
\hline & 193 & 160 & 134 & & & & $=\sqrt{34}=5,83$ \\
\hline & 213 & 185 & 151 & & & & \\
\hline & 182 & 155 & 132 & & & & \\
\hline \multirow{2}{*}{ Grade C } & 189 & 160 & 136 & \multirow{2}{*}{188} & \multirow{2}{*}{160} & \multirow{2}{*}{139} & $\sqrt{(188-181)^{2}+(160-149)^{2}+(139-132)^{2}}$ \\
\hline & $\begin{array}{l}191 \\
170\end{array}$ & $\begin{array}{l}165 \\
141\end{array}$ & $\begin{array}{l}141 \\
122\end{array}$ & & & & $\sqrt{(7)^{2}+(11)^{2}+(7)^{2}}$ \\
\hline
\end{tabular}
euclidean distance, setelah dilakukan perhitungan jarak Euclidean distance kemudian mengumpulkan kelas klasifikasinya, lebih jelas perhitungan dapat dilihat pada Tabel 3.

\section{Tabel 3. Perhitungan Jarak Euclidean}

Ridha, Pemilihan Bibit Kelapa Menggunakan Metode Nearest Mean Classifier Untuk Masyarakat Petani Kelapa Di Kabupaten Indragiri Hilir 


\begin{tabular}{lrrr}
\hline 182 & 155 & 136 & $\sqrt{49+121+49}$ \\
189 & 161 & 138 & $=\sqrt{219}=14,79$ \\
195 & 169 & 148 & \\
212 & 187 & 169 & \\
195 & 173 & 149 & \\
183 & 145 & 120 & \\
180 & 148 & 131 & \\
\hline \hline
\end{tabular}

Tabel 4. Prediksi Nearest Mean Classifier

\begin{tabular}{ll}
\hline Jarak ke citra query [197 171 140] & Kelas Kualitas Nearest mean classifier \\
\hline 18,49 & Grade A 80-85\% \\
5,83 & Grade B 70-75\% \\
\hline 14,79 & Grade C 60-65\% \\
\hline
\end{tabular}

Berdasarkan Tabel 4 jarak terkecil dari 3 jarak , maka dapat diambil kesimpulan bahwa citra query yang memiliki vektor fitur RGB [181 149 132] termasuk kedalam Kelas Grade B 70-75\%

Tabel 5. Database Vektor Fitur Citra Uji

\begin{tabular}{|c|c|c|c|c|c|c|c|c|c|c|}
\hline \multirow[b]{2}{*}{ No } & \multicolumn{3}{|c|}{ Warna RGB } & \multicolumn{4}{|c|}{ Textsture } & \multirow[b]{2}{*}{ Jarak } & \multirow[b]{2}{*}{ (\%) } & \multirow[b]{2}{*}{ Kelas } \\
\hline & Red & Green & Blue & Contrast & correlation & Energy & $\begin{array}{l}\text { Homo- } \\
\text { geneity }\end{array}$ & & & \\
\hline 1 & 197 & 165 & 141 & 0.34102 & 0.8844 & 0.44258 & 0.93037 & 0.330428 & 66.96 & Grade $A$ \\
\hline 2 & 189 & 165 & 141 & 0.3477 & 0.88449 & 0.46412 & 0.93576 & 0.207606 & 79.24 & Grade A \\
\hline 3 & 201 & 172 & 150 & 0.19858 & 0.92978 & 0.41243 & 0.94963 & 0.536621 & 46.34 & Grade A \\
\hline 4 & 195 & 162 & 135 & 0.15248 & 0.95553 & 0.42583 & 0.96984 & 0.399954 & 60 & Grade A \\
\hline 5 & 197 & 171 & 146 & 0.19083 & 0.91921 & 0.50444 & 0.95074 & 0.436817 & 56.32 & Grade A \\
\hline 6 & 196 & 164 & 140 & 0.26337 & 0.92136 & 0.46682 & 0.96309 & 0.292944 & 70.71 & Grade A \\
\hline 7 & 205 & 171 & 139 & 0.21954 & 0.91745 & 0.43591 & 0.95715 & 0.542776 & 45.72 & Grade A \\
\hline 8 & 200 & 171 & 151 & 0.43385 & 0.84292 & 0.43686 & 0.92405 & 0.535985 & 46.4 & Grade A \\
\hline 9 & 201 & 172 & 150 & 0.19858 & 0.92978 & 0.41243 & 0.94963 & 0.536621 & 46.34 & Grade A \\
\hline 10 & 195 & 173 & 150 & 0.66621 & 0.81456 & 0.37999 & 0.91988 & 0.501212 & 49.88 & Grade $\mathrm{A}$ \\
\hline 11 & 169 & 141 & 125 & 0.3566 & 0.91679 & 0.46204 & 0.93431 & 0.588703 & 41.13 & Grade B \\
\hline 12 & 175 & 152 & 130 & 0.63044 & 0.81322 & 0.59353 & 0.93723 & 0.4381 & 56.19 & Grade B \\
\hline 13 & 170 & 143 & 120 & 0.51662 & 0.89499 & 0.3503 & 0.90987 & 0.577785 & 42.22 & Grade B \\
\hline 14 & 179 & 155 & 132 & 0.18739 & 0.94763 & 0.44662 & 0.96662 & 0.370053 & 62.99 & Grade B \\
\hline 15 & 183 & 143 & 125 & 0.5005 & 0.88628 & 0.41405 & 0.93033 & 0.442443 & 55.76 & Grade B \\
\hline 16 & 187 & 147 & 124 & 0.41284 & 0.90136 & 0.41521 & 0.93079 & 0.39475 & 60.53 & Grade B \\
\hline 17 & 179 & 146 & 118 & 0.36522 & 0.92268 & 0.35266 & 0.92219 & 0.495668 & 50.43 & Grade B \\
\hline 18 & 183 & 147 & 116 & 0.26978 & 0.93224 & 0.43549 & 0.94625 & 0.513396 & 48.66 & Grade B \\
\hline 19 & 177 & 144 & 119 & 0.45779 & 0.90731 & 0.39377 & 0.9438 & 0.512364 & 48.76 & Grade B \\
\hline 20 & 178 & 147 & 124 & 0.57499 & 0.873 & 0.41699 & 0.93217 & 0.414226 & 58.58 & Grade B \\
\hline 21 & 184 & 156 & 137 & 0.2825 & 0.91693 & 0.44927 & 0.94638 & 0.598038 & 40.2 & Grade C \\
\hline 22 & 187 & 165 & 151 & 0.59699 & 0.84998 & 0.24348 & 0.85432 & 0.529347 & 47.07 & Grade C \\
\hline 23 & 188 & 158 & 140 & 0.40422 & 0.89383 & 0.38088 & 0.9165 & 0.223277 & 77.67 & Grade C \\
\hline 24 & 183 & 161 & 138 & 0.38606 & 0.88281 & 0.53322 & 0.93886 & 0.506079 & $49 \cdot 39$ & Grade C \\
\hline 25 & 185 & 166 & 146 & 0.24684 & 0.92728 & 0.48688 & 0.94574 & 0.468781 & 53.12 & Grade C \\
\hline 26 & 190 & 159 & 136 & 0.24722 & 0.93015 & 0.4345 & 0.94791 & 0.356312 & 64.37 & Grade C \\
\hline 27 & 189 & 160 & 136 & 0.18885 & 0.92558 & 0.56785 & 0.96571 & 0.301436 & 69.86 & Grade C \\
\hline 28 & 189 & 161 & 138 & 0.29611 & 0.92038 & 0.46095 & 0.95042 & 0.102079 & 89.79 & Grade C \\
\hline 29 & 187 & 160 & 135 & 0.18875 & 0.92441 & 0.51232 & 0.94743 & 0.495049 & 50.5 & Grade C \\
\hline 30 & 190 & 160 & 137 & 0.24722 & 0.93015 & 0.4345 & 0.94791 & 0.219485 & 78.05 & Grade C \\
\hline
\end{tabular}

Tabel 5 merupakan Hasil dari citra uji dari 30 citra uji,dimana masing data 10 grade A, 10 grade $B, 10$ grade $C$ dimana data citra uji itu masing - masing didapat dalam proses Klasifikasi berdasarkan perhitungan citra query dengan menggunkan rumus euclidean distance,kemudian dicari jarak terkecil dalam proses klasifikasi dan perhitungan persentase (\%) kemiripan berdasrkan dari data citra latih. dengan metode Nearest mean classifier, nilai rata-rata terendah dari citra query yang nantinya akan menjadi hasil kualitas bibit kelapa.

Ridha, Pemilihan Bibit Kelapa Menggunakan Metode Nearest Mean Classifier Untuk Masyarakat Petani Kelapa Di Kabupaten Indragiri Hilir 
4. Tahapan Analisa Perancangan Sistem

Pada tahan analisa perancangan sistem peneliti menggunakan Consept Data Modeling (CDM) Context Diagram dan Data Flow Diagram (DFD) Sebagai model sistem untuk mempersentasikan seluruh elemen sistem yang saling terkait baik input,proses dan output,ada beberapa tahapann dalam analisa perancangan sistem yaitu:

a) Tahapan pertama pada analisa perancangan sistem klasifikasi bibit kelapa menggunakan Pemodelan Context Diagram dimana berfungsi untuk menggambar secara umum seluruh input dan output sistem, dapat dilihat pada Gambar 4.

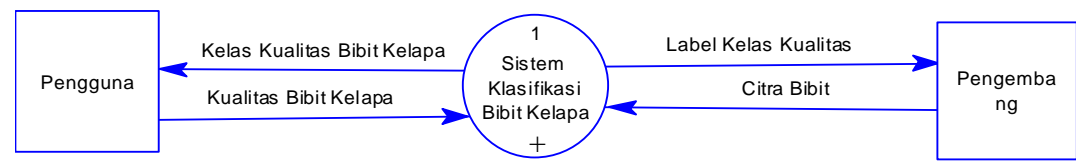

Gambar 4. Context Diagram Klasifikasi Kualitas Bibit Kelapa

Pada Diagram Konteks terdapat di entitas utama yang terlibat yaitu pengembang sistem dan penguna,proses secara umum dimulai dari penginputkan/pengambilan citra bibit kelapa dan background,pada proses klasifikasinya terdapat proses pembentukan kelas,subtraction,ekstraksi fitur,klasifikasi dan evaluasi,dan menghasilkan kelas kualitas bibit kelapa,sedangkan dari sisi entitas pengguna proses ekstraksi kualitas bibit kelapa dan kelas bibit kelapa dimana prosesnya juga berupa subtraction,ekstraksi fitur dan klasifikasi, untuk lebih detailnya digambarkan pada DFD level 1 pada Gambar 5.

b) Data Flow Diagram Level 1

DFD level 1 (satu) digunakan untuk menggambarkan secara detail aliran data sistem klasifikasi bibit kelapa,yang melibatkan data store sebagai tempat penyimpanan dan proses decomposisi sistem,DFD level 1 merupakan gambaran detail dari Context Diagaram, untuk Data Flow Diagram dapat dilihat pada Gambar 6.

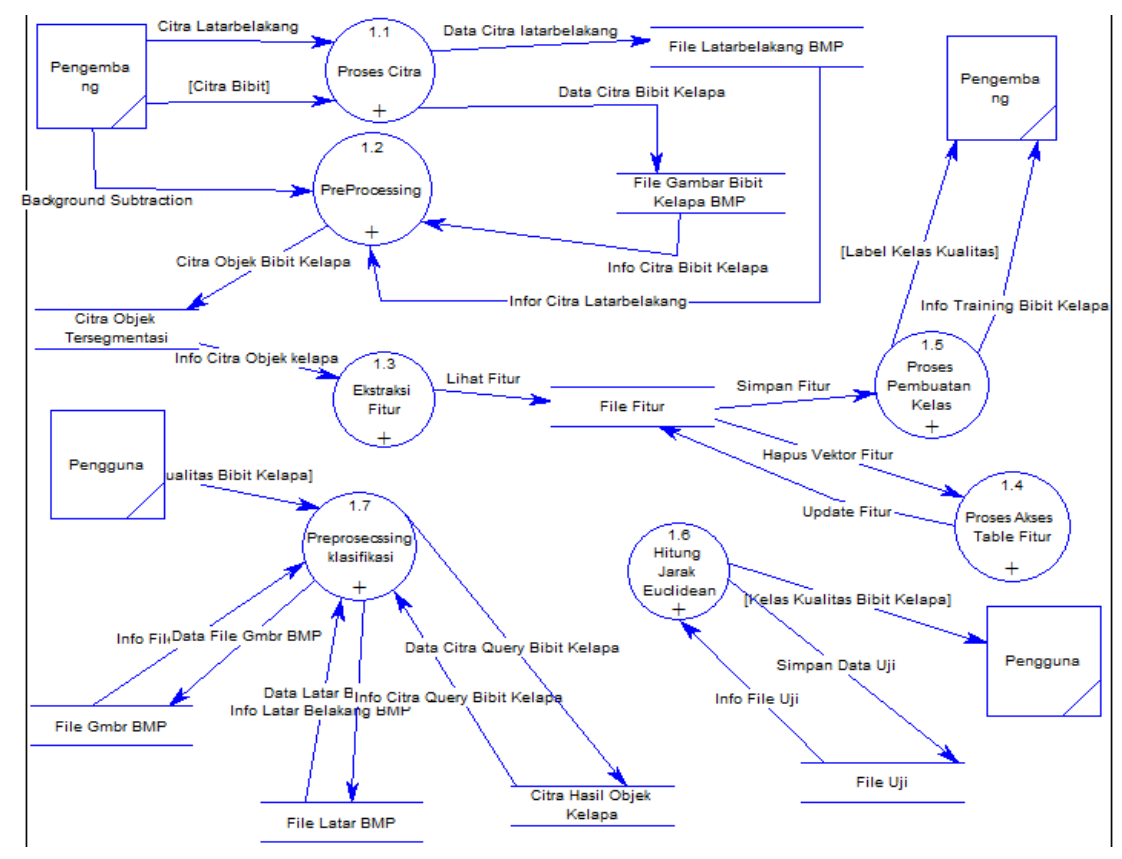

\section{Gambar 5. DVD Level 1 Proses Klasifikasi Kualitas Bibit Kelapa}

Gambar 5 DFD level 1 dimulai pengembang input data citra latar belakang kemudian di proses file citra background BMP,kemudian input citra bibit kelapa dan kemudian diproses pada Filegambar citra kelapa berformat BMP,tahapan selanjutnya proses preprocessing yakni proses background subraction (proses pemisahan background belakang dengan citra gambar 
kelapa) setelah proses pemisahan subtaction selesai, tahapan selanjutnya proses ekstraksi fitur dimana ekstraksi fitur ini akan menghasilkan Fitur RGB (Red, Green ,Blue).setelah ekstraksi, tahap selanjutnya proses pembentukan kelas,dimana proses ini hasilnya disimpan kedalam data store file fitur,tahap selanjutnya proses klasifikasi dimana proses klasifikasi ini menghasilkan RGB (Red, Green ,Blue) dan CCEM (contrast, correlation, energy, homogeneity),akan di simpan kedalam data store citra hasil objek kelapa,proses ekstraksi fitur citra query, setelah menghitung citra quey tahap selanjutnya proses menghitung jarak,dan hasil nya disimpan kedalam data store File Uji,dan akan menghasilkan kualitas bibit kelapa berdasarkan grade $A, B$ atau $C$ dengan persentase kemiripan.

\subsection{Implementasi Sistem}

Implementasi merupakan tahapan menerapkan dan mengoperasikan sistem pada kenyataan yang sebenarnya, sehingga akan di ketahui apakah sistem yang telah dibangun benar-benar dapat berjalan dan sesuai dengan tujuan yang ingin dicapai. Adapun Implementasi Sistem meliputi Sistem pembentuk kelas dan sistem klasifikasi Bibit Kelapa.

1. Implementasi Sistem Pembentuk Kelas. Implementasi Sistem Pembentuk Kelas memerlukan sekumpulan input berupa bibit kelapa yang diambil citranya dengan menggunakan kamera untuk dijadikan referensi. Fase pengumpulan sample bibit kelapa ini disebut dengan fase pelatihan. Sistem dikenalkan dengan berbagai sekelompok bibit kelapa dengan fitur warna dan fitur tekstur. Sistem pembentuk kelas juga akan menampilkan output berupa tabel yang akan menampilkan bibit kelapa yang sudah diperkenalkan, dimana masing-masing bibit kelapa diwakili oleh mean kelasnya. Untuk memudahkan proses pelatihan yang akan dilakukan maka diperlukan antar muka pemakai untuk melaksanakan fase pelatihan tersebut. Pada Gambar 6 ditunjukkan tampilan antar muka sistem pembentuk kelas.

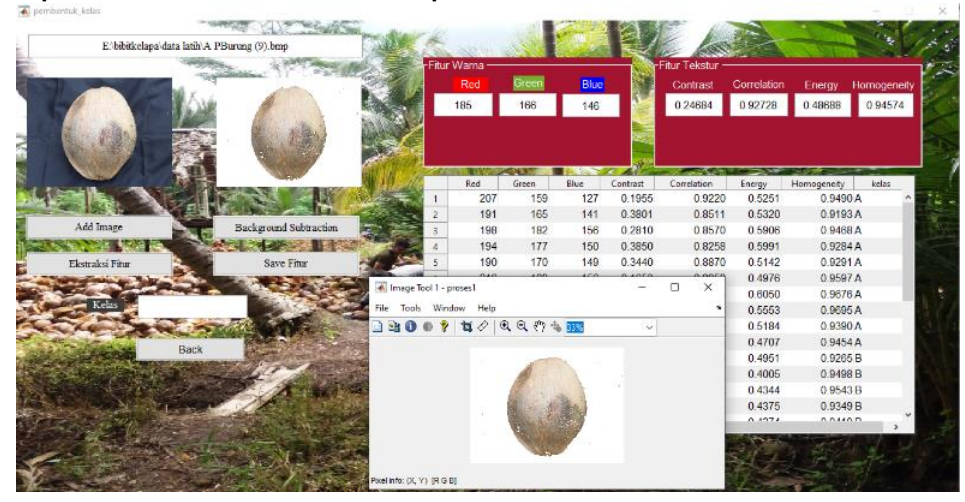

\section{Gambar 6. Halaman Sistem Pembentuk Kelas}

Antar muka Gambar 6 di atas terdapat beberapa tombol-tombol yang dapat dipergunakan oleh user untuk melakukan kegiatan pelatihan sistem menggunakan file citra latih. Adapun tombol-tombol yang digunakan adalah sebagai berikut:

a) Tombol add image untuk memulai melakukan pelatihan kepada sistem dengan membaca file citra latih.

b) Tombol background subtract untuk memisahakan citra objek buah dari latar.

c) Tombol ekstraksi fitur untuk melakukan proses ekstrak pada citra sampel bibit kelapa.

d) Tombol save fitur digunakan untuk menyimpan hasil ekstraksi ke dalam Basis data Fitur Citra bibit kelapa.

e) Tombol back adalah tombol kembali kehalaman utama.

2. Proses Ekstraksi Fitur. Setelah menentukan citra objek buah yang akan dijadikan referensi oleh sistem maka citra buah tersebut di ekstraksi oleh sistem pembentuk basis data. Hasil ekstrak adalah vektor fitur yang selanjutnya akan disimpan dalam table Fitur Citra melalui proses akses basis data. Adapun contoh hasil ekstraksi fitur tersebut seperti pada Gambar 7 berikut ini. 


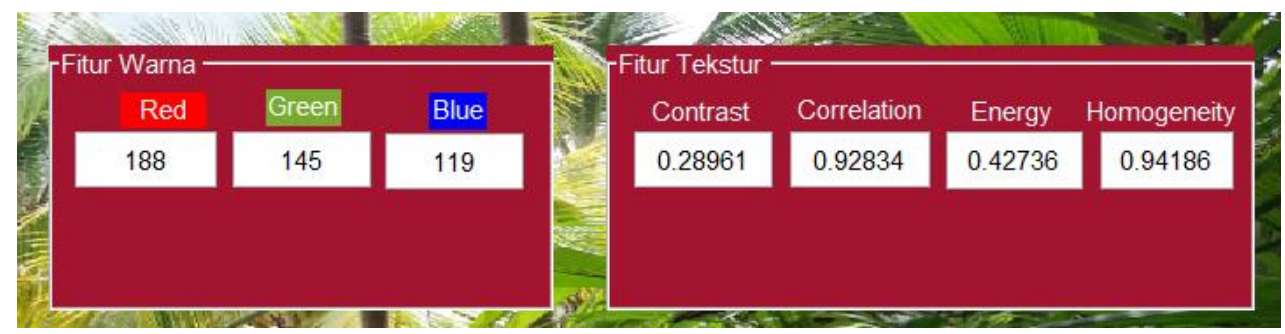

Gambar 7. DVD Level 1 Proses Ekstraksi Fitur

3. Proses Klasifikasi. Proses Klasifikasi bibit kelapa memerlukan sekumpulan input berupa bibit kelapa yang akan diambil citranya untuk dikenali dan diklasifikasikan dan menghasilkan outpun informasi jarak, prosentase kemimiripan dan informasi kelas kualitas bibit kelapa. Selain bibit kelapa yang di inputkan kedalam sistem klasifikasi akan menolak kerena prosentase kurang dari $<40$ \% klasifikasi penolakan kelapa. Perhatikan Gambar 8 berikut ini.

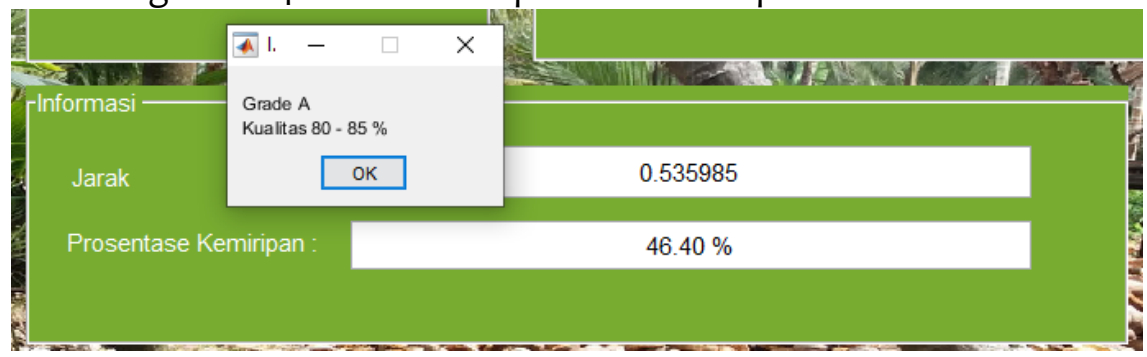

(a)

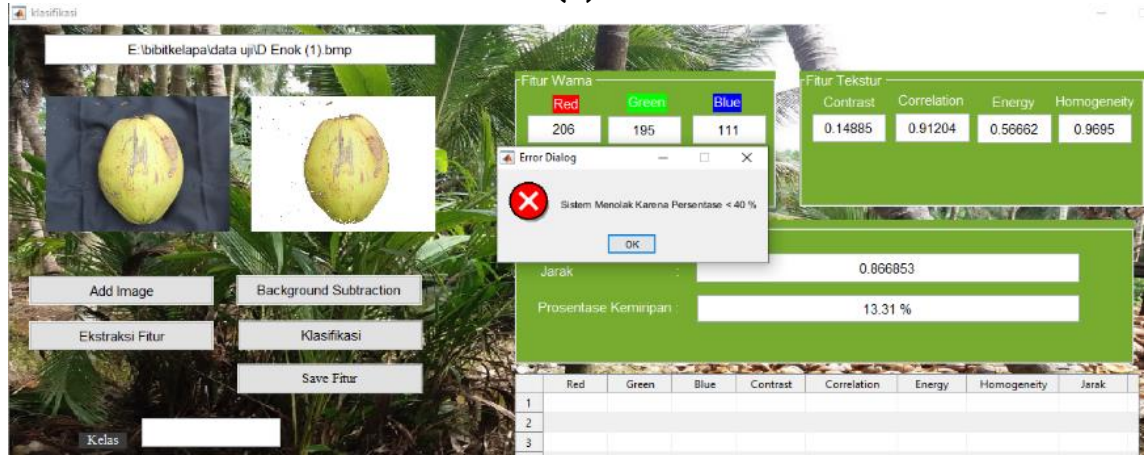

(b)

Gambar 8. (a) Proses Klasifikasi poin a (b) Penolakan Klasifikasi poin b

5. Proses Evaluasi. Proses evaluasi adalah pengukuran atau penilaian dari data latih 30 sampel dan data uji 30 sampel dengan metode 10 x10 - flod crossvalidation dan menghasilkan informasi hasil akhir evaluasi dari data eksperimen secara global, memiliki ketelitian rata-rata $86.67 \%$. Perhatikan Gambar 9.

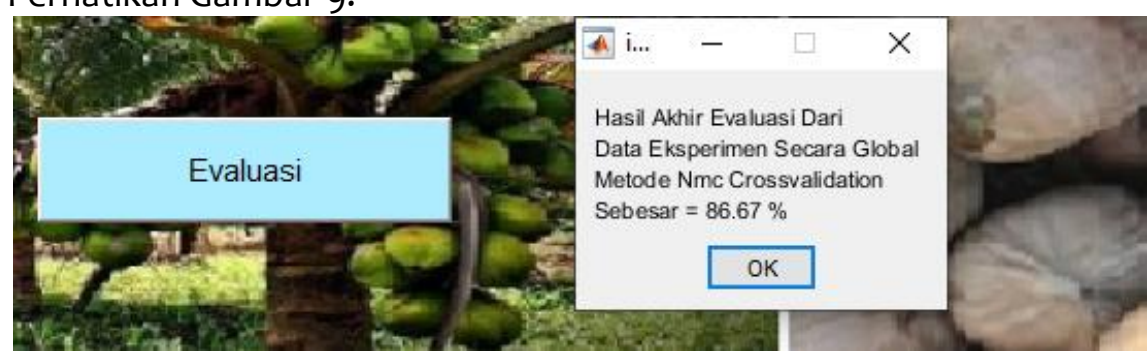

Gambar 11. Proses Evaluasi 


\subsection{Pengujian Sistem}

Uji coba sistem dan program adalah dimana program atau aplikasi yang selesai dirancang, diuji kelayakannya untuk mengetahui apakah sistem tersebut masih terdapat kesalahan eksekusi dan kekurangan atau sudah sesuai dengan tujuan yang diharapkan.

1. Pengujian Sistem Grade A rata -rata 80-85\%

Pengujian sistem Grade A adalah pengujian klasifikasi dari data uji, 10 data eksperimen yang menghasikan informasi berupa jarak dan prosentase kemiripan. Dapat dilihat pada Tabel 7.

Tabel 6. Pengujian Sistem Grade A Rata-Rata $80-85 \%$

\begin{tabular}{cccl}
\hline No & Grade & \multicolumn{1}{c}{ Jarak } & $\begin{array}{c}\% \\
\text { Kemiripan }\end{array}$ \\
\hline 1 & Grade A & 0,330428 & 66,96 \\
2 & Grade A & 0,207606 & 79,24 \\
3 & Grade A & 0,536621 & 46,34 \\
4 & Grade A & 0,399954 & 60 \\
5 & Grade A & 0,436817 & 56,32 \\
6 & Grade A & 0,292944 & 70,71 \\
7 & Grade A & 0,542776 & 45,72 \\
8 & Grade A & 0,535985 & 46,4 \\
9 & Grade A & 0,536621 & 46,34 \\
10 & Grade A & 0,501212 & 49,88 \\
& Rata - Rata & 0,4320964 & 56,791 \\
\hline \hline
\end{tabular}

2. Pengujian Sistem Kelas Grade B rata-rata $70-75 \%$

Pengujian sistem kelas Grade B 70-75\% adalah pengujian klasifikasi dari data uji, 10 data eksperimen yang menghasikan informasi berupa jarak dan prosentase kemiripan. Dapat dilihat pada Tabel 7.

Tabel 7. Pengujian Sistem Grade B Rata-Rata 70-75\%

\begin{tabular}{ccll}
\hline No & Grade & Jarak & $\begin{array}{c}\% \\
\text { Kemiripan }\end{array}$ \\
\hline 1 & Grade B & 0,588703 & 41,13 \\
2 & Grade B & 0,4381 & 56,19 \\
3 & Grade B & 0,577785 & 42,22 \\
4 & Grade B & 0,370053 & 62,99 \\
5 & Grade B & 0,442443 & 55,76 \\
6 & Grade B & 0,39475 & 60,53 \\
7 & Grade B & 0,495668 & 50,43 \\
8 & Grade B & 0,513396 & 48,66 \\
9 & Grade B & 0,512364 & 48,76 \\
10 & Grade B & 0,414226 & 58,58 \\
& Rata - Rata & 0,4747488 & 52,525 \\
\hline \hline
\end{tabular}

3. Pengujian Sistem Kelas Grade C rata - rata60-65\%

Pengujian sistem kelas Grade C 60-65\% adalah pengujian klasifikasi dari data uji, 10 data eksperimen yang menghasikan informasi berupa jarak dan prosentase kemiripan. Dapat dilihat pada Tabel 8. 
Tabel 8. Pengujian Sistem Grade C Rata-Rata 60-65\%

\begin{tabular}{clll}
\hline No & Grade & Jarak & $\begin{array}{c}\% \\
\text { Kemiripan }\end{array}$ \\
\hline 1 & Grade C & 0,598038 & 40,2 \\
2 & Grade C & 0,529347 & 47,07 \\
3 & Grade C & 0,223277 & 77,67 \\
4 & Grade C & 0,506079 & 49,39 \\
5 & Grade C & 0,468781 & 53,12 \\
6 & Grade C & 0,356312 & 64,37 \\
7 & Grade C & 0,301436 & 69,86 \\
8 & Grade C & 0,102079 & 89,79 \\
9 & Grade C & 0,495049 & 50,5 \\
10 & Grade C & 0,219485 & 78,05 \\
& Rata - Rata & 0,3799883 & 62,002 \\
\hline \hline
\end{tabular}

Dari hasil pengujian setiap tabel memiliki 10 eksperimen. Dari 10 eksperimen diklasifikasikan menghasilkan informasi jarak dan prosentase kemiripan. Dari hasil data jarak dan prosentase kemiripan di jumlahkan. Dari hasil jumlah dibagi 10. Adapun Tabel 6, Tabel 7 dan 8. Klasifikasi tertinggi ditunjukkan pada Tabel 3 dengan jarak 0,3799883\% dan prosentase kemiripan $62 \%$. Bisa dilihat di Tabel 9 di bawah ini.

\section{Tabel 9. Keseluruhan Rata-Rata Kelas}

\begin{tabular}{ccccccc}
\hline & \multicolumn{3}{c}{ Jarak } & & \multicolumn{3}{c}{ Kemiripan } \\
& Kelas A & Kelas B & Kelas C & Kelas A & Kelas B & Kelas C \\
\hline Rata-Rata & 0,4320964 & 0,4747488 & 0,3799883 & 56,791 & 52,525 & 62,002 \\
\hline Simpangan Baku & 0,12056431 & 0,07480268 & 0,16369349 & 12,05715 & 7,481074 & 16,36763 \\
\hline
\end{tabular}

\section{KESIMPULAN}

Berdasarkan dari tujuan penelitian didapat kesimpulan yaitu: Telah dibangun sebuah sistem klasifikasi bibit kelapa menggunakan dengan metode Nearest Mean Classifier (NMC) Dengan Graphical User Interface (GUI) menggunakan tool Matlab. Hasil klasifkasi sistem $10 \times 10$ - fold crossvalidation pada masing-masing katagori yaitu: a. katagori klasifikasi kualitas bibit kelapa Grade A (80-85\%) dihasilkan ketelitian rata-rata 56,791\% dengan simpangan baku 12,05715\%; b. katagori kualitas bibit kelapa Grade B (70-75\%) rata-rata dihasilkan ketelitian 52,525\% dengan simpangan baku 7,481074\%; c. katagori kualitas bibit kelapa Grade C(60-65\%) rata-rata dihasilkan ketelitian 62,002 \% dengan simpangan baku 16,36763\%. Dari hasil 10 eksperimen diklasifikasikan menghasilkan informasi jarak dan prosentase kemiripan. Dari hasil didapat adalah Grade $C$ yang memiliki persentase tertinggi dengan jarak 0,379\% dan prosentase kemiripan $62 \%$. Bisa dilihat di Tabel 4 di bawah ini. Hasil akhir evaluasi dari data eksperimen secara global, memiliki ketelitian ratarata $86.67 \%$. Untuk mendapatkan persentase kemiripan yang tinggi harus dilakukan data latih yang banyak terhadap sistem klasifikasi kualitas bibit kelapa.

\section{REFERENSI}

[1] Abdullah, Usman and Efendi, "Sistem Klasifikasi Kualitas Kopra Berdasarkan Warna dan Tekstur Menggunakan Metode Nearest Mean Classifier (NMC)," Jurnal Teknologi Informasi dan Ilmu Komputer, vol. 4, no. 4, pp. 297-303, 2017.

[2] D. L. Rahmah, "Perancangan Aplikasi Sistem Persuratan Berbasis Web Pada PT. Dwi Pilar Pratama," Faktor Exacta, vol. 6, no. 2, pp. 282-292, 2014.

[3] F. A. Hermawati, Data Mining, Yogyakarta: Andi, 2013. 
[4] H. A. Musril, "Studi Komparasi Metode Aritmatic Coding dan Huffman Coding Dalam Algoritma Entropy Untuk Kompresi Citra Digital," Jurnal Teknologi Informasi \& Pendidikan, vol. 5, no. 2, pp. 133-156, 2012.

[5] Y. Permadi and Muritno, "Aplikasi Pengolahan Cotra Digital Untuk Identifikasi Kematangan Mentimun Berdasarkan Tekstur Kulit Buah Menggunakan Metode Ekstraksi Ciri Statistik," Jurnal Informatika, vol. 9, no. 9, pp. 1028-1038, 2015.

[6] M. Masril, "Implementasi Jaringan Saraf Tiruan Pada Pattern Recognition (Studi Kasus Huruf Jepang Katakana)," Jurnal Teknologi Informatika \& Pendidikan, vol. 6, no. 1, pp. 55-65, 2013.

[7] Pracaya and P. C. Kahono, Kiat Sukses Budidaya Kelapa, Klaten: PT Macanan Jaya, 2011. 